\title{
HYDRAULIC RESEARCH OF SEDIMENT TRANSPORT IN THE VERTICAL SLOT FISH PASSES
}

\author{
Justyna Mumot ${ }^{1}$, Tomasz Tymiński ${ }^{1}$ \\ 1 Instutute Environmental Engineering, Wrocław University of Environmental and Life Sciences, Plac \\ Grunwaldzki 24, 50-365 Wrocław, Poland, e-mail: justyna.mumot@up.wroc.pl
}

Received: 2015.11 .20

Accepted: 2015.12.09

Published: 2016.01.06

\begin{abstract}
The physical model of vertical slot fishway was conducted. On the fishway a device used for sediment dispense was installed. The sediment was dispensed to each chamber. Measurements of approx. height of the water table, measurements of flow rate, observation of line streams in chambers were carried out during the studies. The flows of sediment and hydraulic parameters inside designed fishway, single compartments and their connection with sedimentation process in individual chambers were also studied. the obtained research results constitute starting point for experimental analyses and research analyses. Based on the observation and measurements it is possible to state that the constructed physical model reflects the activity conditions of the vertical slot fishway. During the studies a place of deposition in sediments of individual fishway chambers were determined.
\end{abstract}

Keywords: vertical slot fishway, physical model, flow conditions, sediment.

\section{INTRODUCTION}

All fish migrate, which results from different needs of individual species. Migration results from a need to change the place for preying, in search for food, as well as to spawn. Very often migrating fish have obstacles ahead, particularly when it is an upriver migration. They face a different kind of stackings, steps, thresholds, etc. Structures, which maintain biological continuity in rivers, are fishways. Built on stacking they enable fish migration up and down watercourse. Fishway must be designed and constructed so that combination of upper and lower level was concatenation (that gives possibility to rest for fish after defeating each stage) or mild connection (ramp). A fishway is a building, which eliminates large local slope of water table on a longer stretch of river. In fishway the flow rate of water should enable aquatic organism upstream migration. Frequent problem, which appears in fishways operation, is sediment deposition, which accumulates due to insufficient flow rate of water in the fishway. What is even more important, sediment de- position in the fishway prevents aquatic organism migration through fishway.

\section{AREA OF RESEARCH}

Figure 1 shows a general schematic of the measurement set-up together with the supply installation. Studies were carried out in the opened rectangular flume of concrete bottom $L$ $=13.50 \mathrm{~m}$ in length and $B=0.96 \mathrm{~m}$ in width. The vertical slot fishway model built from PCV panels of thickness of $10 \mathrm{~mm}$ was mounted in this rectangular flume. Main fishway, modeling plate of riverbed bottom, upper control section, outlet section and stacking valve consisted the model. The fishway was a channel with length $L p=2.10 \mathrm{~m}$, internal width $b p=0.25 \mathrm{~m}$, heights of side partition walls $h=0.18 \mathrm{~m}$ and constant bed slope 1:10. The flume of the fishway was divided into 7 chambers (Figure 2) of fixed compartments with a slot width $s=40 \mathrm{~mm}$. Maximum discharge of the closed circulation system was $Q=40.701 \cdot \mathrm{s}^{-1}$. 
9- Transfer of circular

10- Measuring trough

11- Model fishway

12- Latch on fishway

13- Gate to outlet trough

14- The water outlet hose from the trough

15- Trolley with measuring

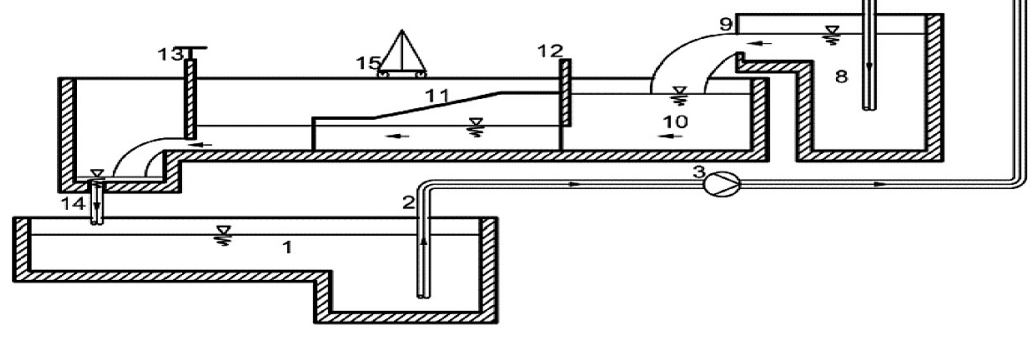

Figure 1. Outline of the measuring system
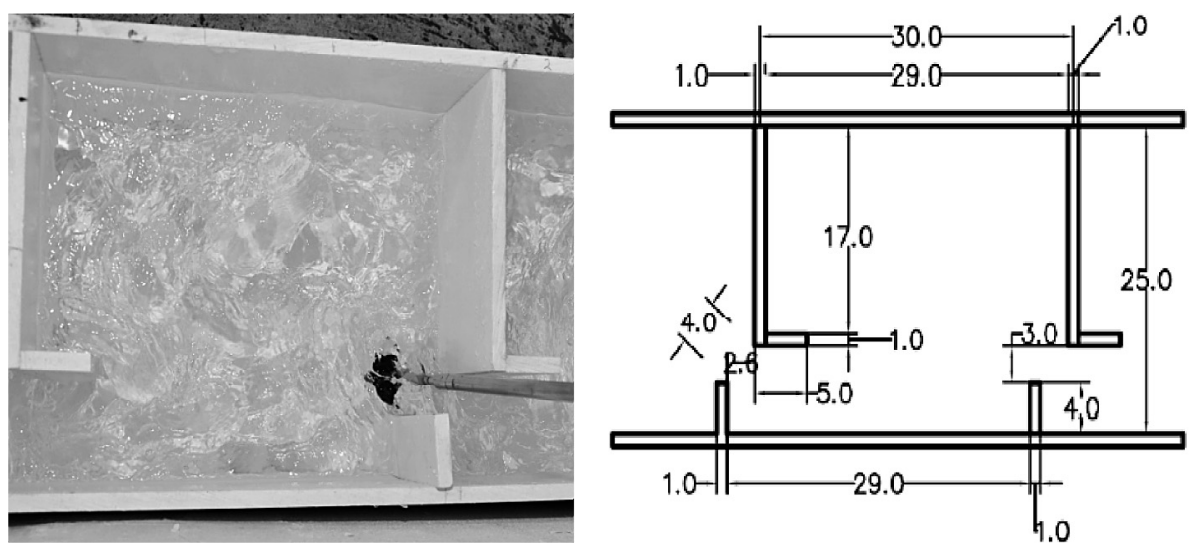

Figure 2. On the right view on the chamber in fishway while measurement with probe (probe is on the right) on the left view the dimensions of the chamber of fishway

\section{METHODOLOGY}

In the course of research measurements of elevation height of the water level, flow velocity measurements in different chambers in fishway were carried out and sediment deposition in each chamber in fishway were analyzed. Sediment deposition in each chamber was analyzed in the fishway.

Measurements of the water table height were carried out using a needle streamgauge and a cathetometer. Measurements were carried out in the middle of chamber length near partition wall on opposite slot side. During the studies, 10 measuring series were carried out. The number of measuring points in series from 3 to 14 (points depend on the places we have laid down over debris). Multidirectional measurements of local velocity in chambers were carried out using electromagnetic probe of PEMS type. Accuracy of measurement was $\pm 0.001 \mathrm{~m} \cdot \mathrm{s}^{-1}$. The measurements were conducted in the middle of depth in fishway chambers at characteristic points of flow disturbance and at points located in a grid of squares, as well as on inlet and outlet from the chamber.

Sediment was dispensed to the first chamber with a sediment dispenser (Figure 3). The sediment of sand faction (fine sand and medium sand) was dispensed with grains diameter of $0.125 \mathrm{~mm}, 0.5 \mathrm{~mm}$ and $1 \mathrm{~mm}$. Next, the sediment was dispensed right behind the intake in GK1 chamber, all the way to $\mathrm{K} 5$ chamber.

In a container an agitator was installed with electric motor and adjusted speed of turnovers. Agitator's work disqualified sedimentation process of particles inside the container during dispense of research material. A hole is in the bottom of the container through which flows dispensed the material. Next, the sediment flows through wire (PCV tube) with a diameter of $0.010 \mathrm{~m}$, at the end of which the tube dispensing samples, horizontally located, with a width corresponding to the width of the 


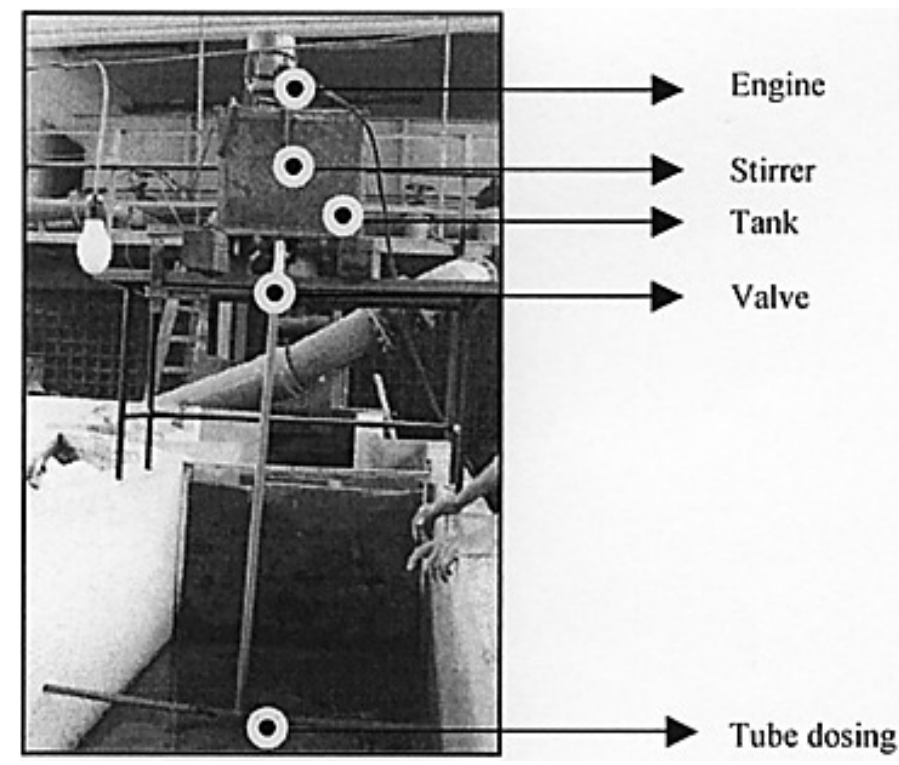

Figure 3. Sediment dispenser

riverbed i.e. $0.96 \mathrm{~m}$. In the tube there are 7 holes with diameter of $0.02 \mathrm{~m}$ about permanent gauge, through which the sediment flows freely into the riverbed.

\section{RESULTS AND DISCUSSION}

Sediment dispense was held in a constant way right above water table from upper position in the first chamber on its entire widths. Studies were always carried out at the constant flow of water $\left(Q=201 \cdot \mathrm{s}^{-1}\right)$. It was a flow, by which particles were transported in the entire profile of fishway. In addition, there was also deposition of about $70 \%$ sediment particles at the bottom, which was important for research. On the bottom grains of size $1 \mathrm{~mm}$ settled quite fast. Grains with a diameter of $0.125 \mathrm{~mm}$ and $0.5 \mathrm{~mm}$ were transported to a further chambers of fishway $30 \%$. In Figure 4 up to Figure 7 a horizontal distribution of flow velocity and sediment deposition in chambers of fishway are presented.

Due to specific local velocity distribution in the chambers GK1 (Figure 4) and GK3 (Figure 5 ) the sediment have been deposited almost over the entire surface of the chamber. However, in the chambers K1 (Figure 6) and K3 (Figure 7) the sedimentation was observed only in a small

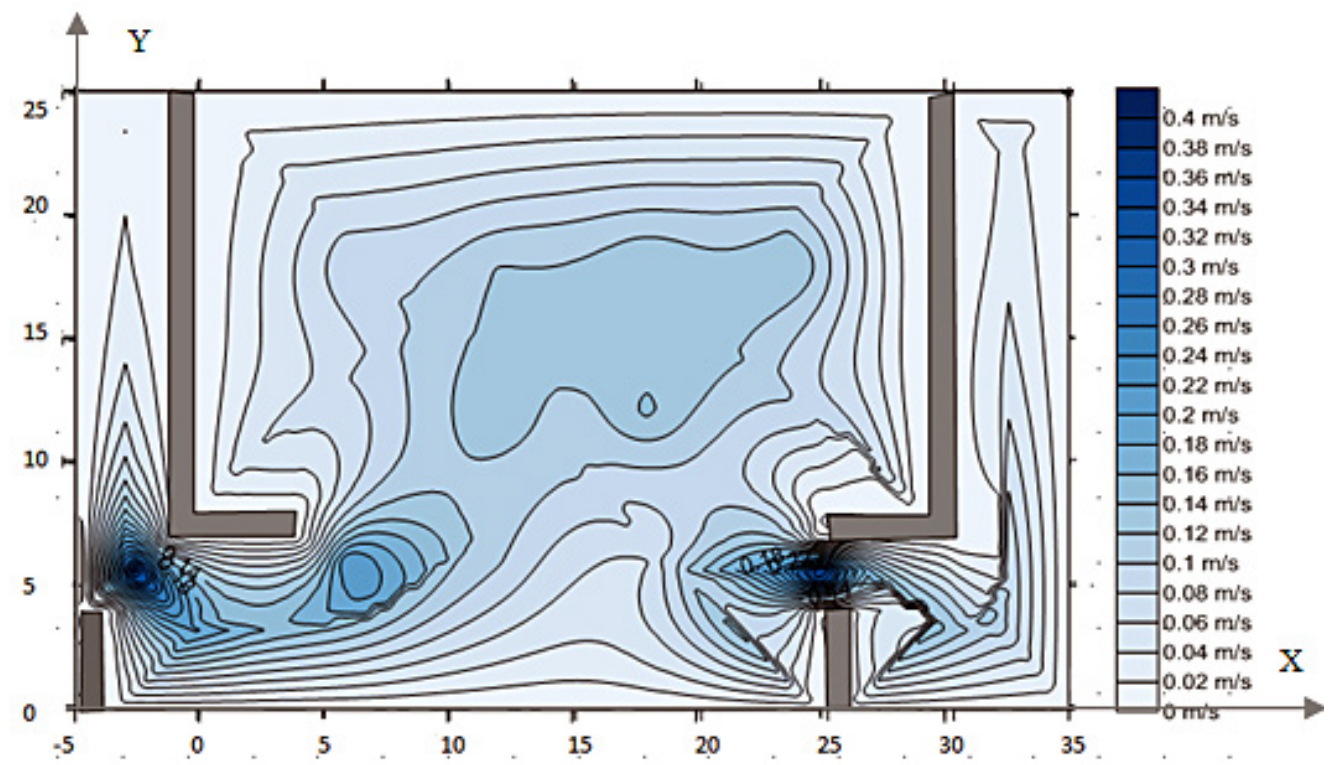

Figure 4. Horizontal distribution of flow velocity in GK1 chamber 


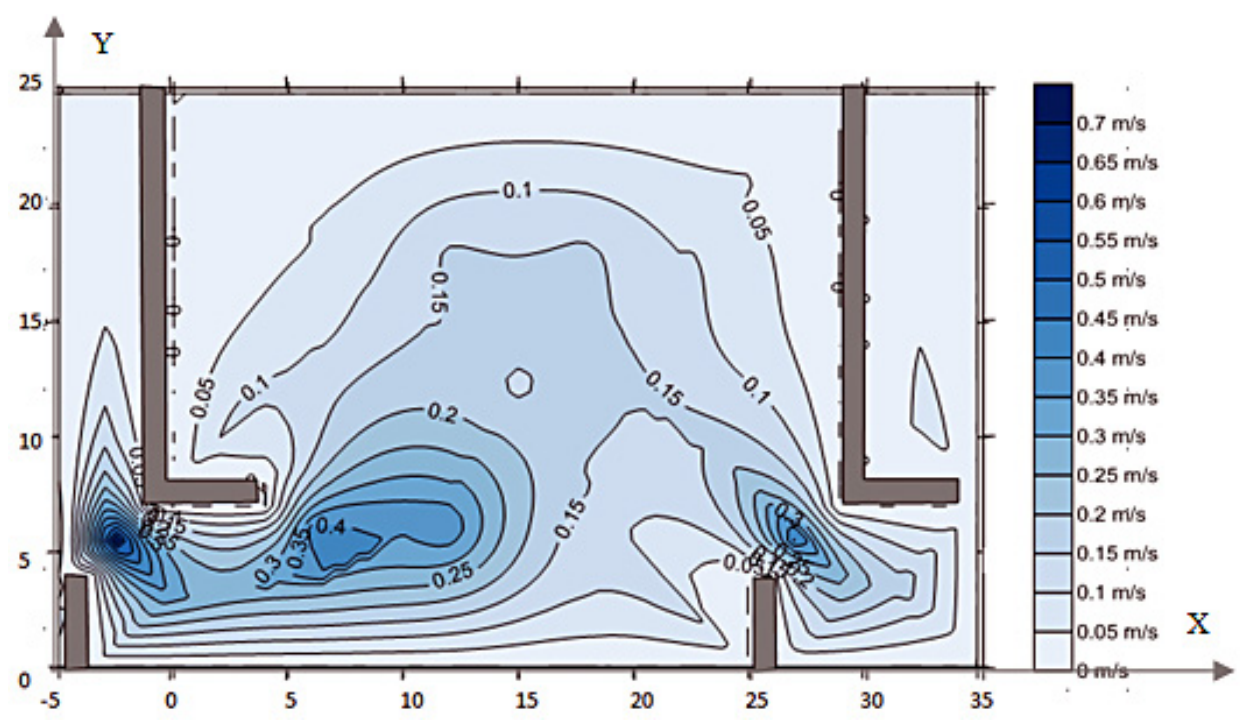

Figure 5. Horizontal distribution of flow velocity in GK3 chamber
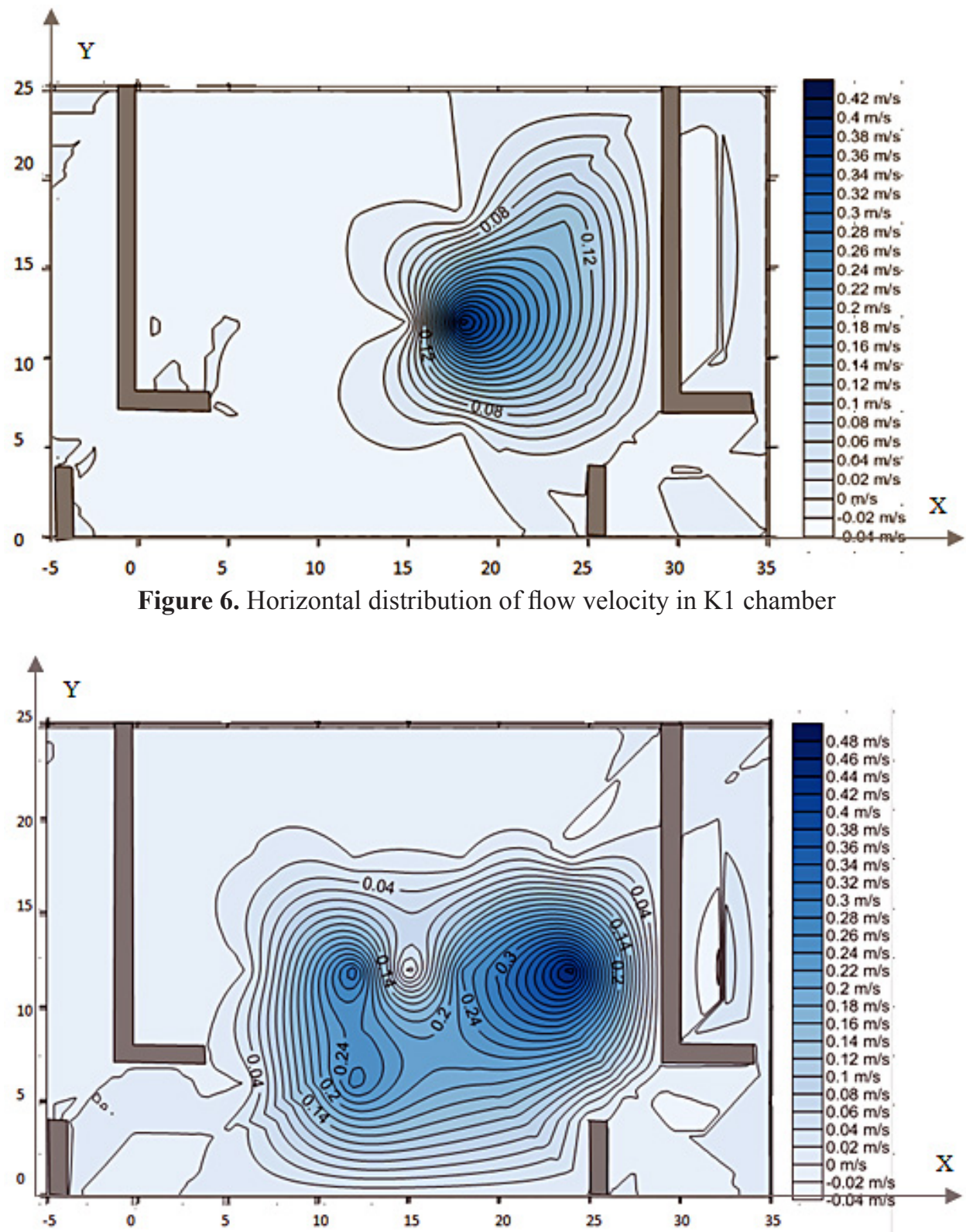

Figure 7. Horizontal distribution of flow velocity in K3 chamber 
area. The greatest local momentary velocities of water flow occur in the first chamber GK1. Higher velocities can also be observed in the chamber GK3 (at the inlet of proper fishway). In all cases, the highest local velocities occur at the outlet and inlet of the fishway chamber. However the smallest local velocities appear at partition wall and in the corners of chamber.

In Figures 8 and 9 dispense and deposition of sediment was observed. Figure 8 presents how sediment distributes, which was dispensed before inlet to fishway by the first GK1 chamber. Whereas, Figure 9 presents what sediment deposition looks like in the third GK3 chamber. In this case, the sediment was dispensed right behind inflow in the first chamber. In Figures 10 and 11 sediment deposition was presented after 10 minutes of studies at constant flow rate and single dispense of sediment from the GK1 chamber downstream to the $\mathrm{K} 5$ chamber.

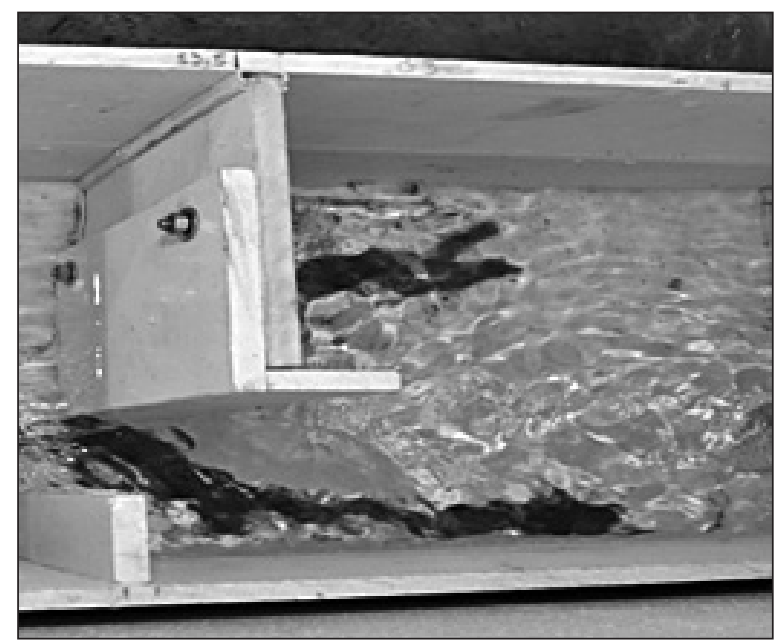

Figure 8. Sediment deposition in GK1 chamber

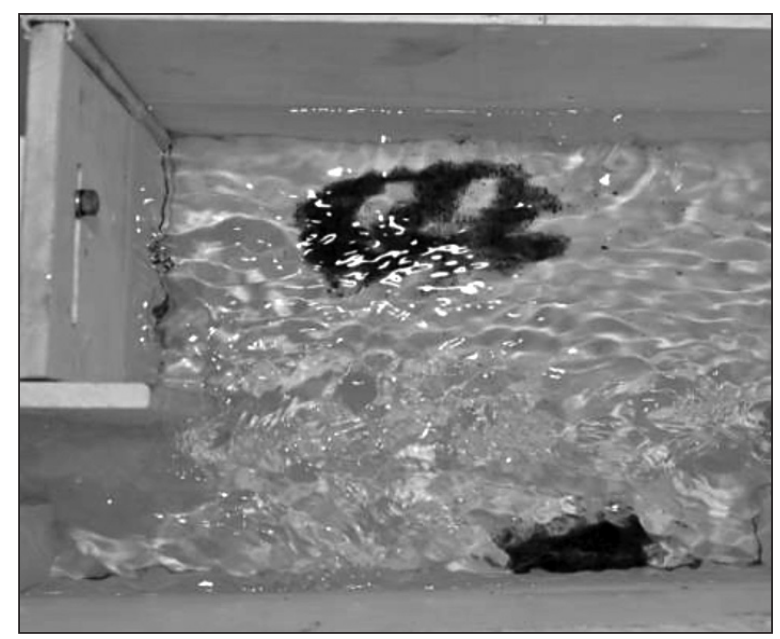

Figure 10. Sediment deposition in GK1 chamber after 10 minutes research

\section{CONCLUSIONS}

Based on conducted observation and measurements it is possible to state that physical model reflects activity conditions of vertical slot fishway. With established parameters (fixed $Q$ and appropriate grain size) it is possible to notice places in which sediment deposition is held. With grains about diameter $0.125 \mathrm{~mm}, 0.5 \mathrm{~mm}$ and 1.0 $\mathrm{mm}$ in quite a short time it is possible to observe phenomenon of sedimentation and sediment deposition ( $70 \%$ of all grains). Particularly the bigger grains with diameter $d=1.0 \mathrm{~mm}$ sedimented relative fast. About $60 \%$ of smaller grains (these with $d=0.125 \mathrm{~mm}$ and $0.5 \mathrm{~mm}$ ) were transported downstream to the next chambers. After conducted laboratory investigation it can be notice that:

- there is a clear relationship between the hydraulic flow conditions and sediment transport in the fishway,

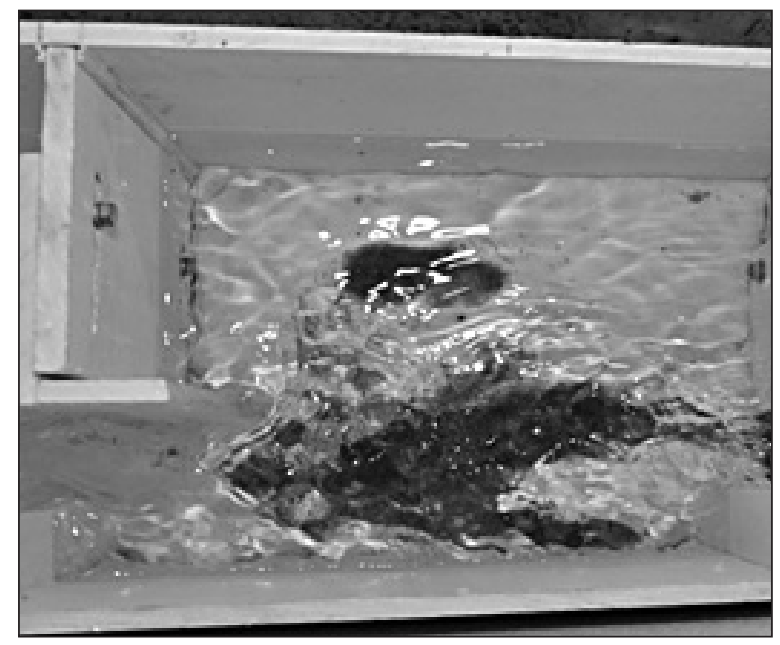

Figure 9. Sediment deposition in GK3 chamber

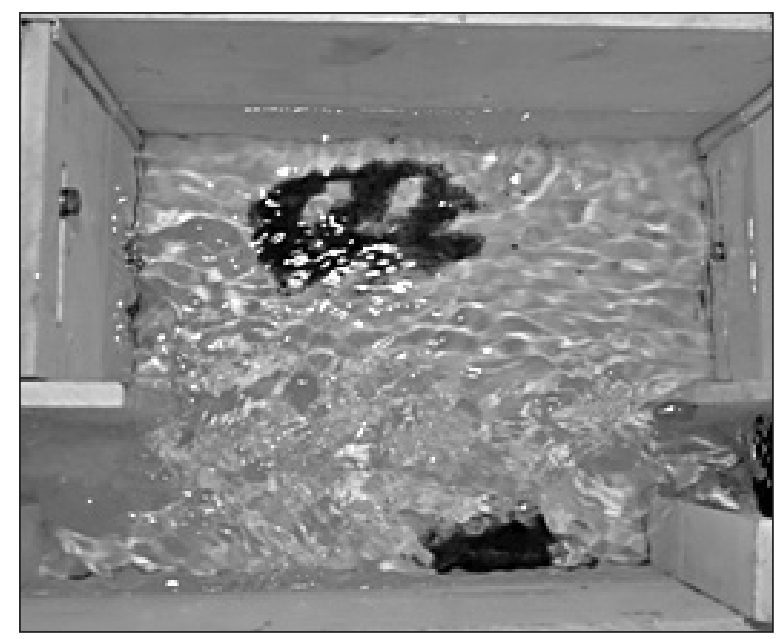

Figure 11. Sediment deposition in GK3 chamber after 10 minutes research 
- sediment transport and sedimentation significantly depend mainly on the sediment properties and spatial distribution of flow velocity,

- much lower mean velocity in GK1, GK2 and GK3 chambers, which result for a lack of stream slope in the bottom,

- the only zones of increased rate are places in vicinity of intake and outlet slot,

- sediment deposition appears in the middle of chamber and by side partition walls,

- the course of sediment transport in time in the fishway is not homogeneous,

- presented results should be considered as preliminary studies of reconnaissance nature, which will be continued (also in a wider range).

\section{REFERENCES}

1. Bartnik W., 1991. Determination of the critical conditions of incipient motion of bed load in mountain rivers. In: Armanini A., Di Silvio G. (Eds.) Lecture Note in Earth Sciences. Fluvial Hydraulics of Mountain Region, Berlin, 37.

2. Bialik R., 2009. Numeryczne modelowanie transportu rumowiska wleczonego. ACTA Scient. Pol., Formatio Circumiectus 9 (2) [in Polish].

3. DVWK, 1996. Fischaufstieganlagen: Bemessung, Gestaltung, Funktionskontrolle. Merkblätter zur Wasserwirtschaft, Bonn, Nr. 232 [in German].
4. FAO-UN, 2002. Fish passes - design, dimensions and monitoring. FAO-UN, DVWK-Germany, Rome.

5. Gessler J. 1971. Beginning and ceasing sediment motion. In: Shen H.W. (Ed.) River Mechanics, Chapt. 7.

6. Głowski R., Kasperek R., Parzonka W., 2010. Wstępna analiza transportu rumowiska unoszonego w przekroju wodowskazowym Chałupki na granicznym odcinku górnej Odry. ACTA Scient. Pol., Formatio Circumiectus 9 (2) [in Polish].

7. Graf W.H., 1978. The modes of sediment transport and their related bed forms in conveyance systems. In: Proceedings of the Conference "Advances in sediment transport", Jabłonna. Ossolineum, Wrocław.

8. Krüger F., 2008. Anforderungen an Fischaufstiegsanlagen, Beispiele aus der Praxis. Konferenzmaterialien: Vortrag zum Wasserbaulichen Kolloquium "Oekologische Durchgängigkeit von Fließgewässern“, Universität Hannover [in German].

9. Larinier M., 2002. Buffle Fishways, Bull. Fr. Peche Piscic. 364 suppl. 2002: Lowe M., Associates Hydrologic Solution "Preliminary fish ladder concept design for Corte Madera Creek flood Control channel, for transition between units three and four".

10. Radecki-Pawlik A., 2014. Hydromorfologia rzek i potoków górskich. UR, Kraków [in Polish].

11. Rajaratmam N., Eed S.A., Katapodis C., 2002. Generalized study of hydraulic of culvert fishways. Journal of Hydraulic Engineering. 